Open Access

\title{
Joint ownership by farmers and investors in the agri-food industry: an exploratory study of the limited cooperative association
}

\author{
Jasper Grashuis (D
}

Correspondence: grashuisj@missouri.edu

Department of Agricultural and Applied Economics, University of Missouri, 135C Mumford Hall, Columbia, MO 65211, USA

\begin{abstract}
Since the 1990s, producers of farm commodities have been attempting to enter value-added agri-food sectors by means of joint ownership of hybrid cooperatives. New generation cooperatives, characterized by substantial supply and equity requirements, inspired much farm producer optimism before revealing weaknesses and limitations in the early 2000s. In response, recent innovations in US cooperative state law introduced the limited cooperative association (LCA), a new legal entity allowing joint ownership by member patrons and member investors to facilitate large-scale equity acquisition. However, business registration data indicate few such organizations have been formed in the agri-food industry. The LCA is adopted by several small-scale operations in niche markets such as lamb, elderberry, and non-GMO seed, but there is not much interest among business organizations in the commodity sector. This paper raises possible explanations for the limited adoption of the LCA, including the competing objectives of farmers and investors, the ambiguous legal interpretation of investor objectives, the superiority of other legal structures, and the lack of strategic advantages. The conclusion facilitates an invitation to further study the challenging future of farmer cooperatives in the agri-food industry.
\end{abstract}

Keywords: Agricultural cooperative, Ownership structure, Property rights, Limited cooperative association

JEL codes: D23, D71, L23, M13, Q13

\section{Introduction}

For farm producers, ongoing consolidation at every stage of the value chain is increasing competition for scarce marketing opportunities (Saitone and Sexton 2017). To stay relevant, many producers of farm commodities have been seeking greater involvement in the processing stage of the agri-food value chain by means of joint ownership of cooperatives. However, traditional cooperatives have an inherent equity constraint and thus limited potential for large-scale investments. In response, in the 1990s, farm producers in the Upper Midwest adopted the new generation cooperative (NGC), an organizational form characterized by substantial supply and equity commitments to collectively add value to milk, corn, buckwheat, and other commodities in times of low prices (Harris et al. 1996; Patrie 1998). However, the conversions of several large NGCs in the 2000s revealed the weaknesses and limitations of traditional cooperatives had not been solved (Grashuis and Cook 2018).

(c) The Author(s). 2018 Open Access This article is distributed under the terms of the Creative Commons Attribution 4.0 International License (http://creativecommons.org/licenses/by/4.0/), which permits unrestricted use, distribution, and reproduction in any medium provided you give appropriate credit to the original author(s) and the source, provide a link to the Creative Commons license, and indicate if changes were made. 
The struggle of traditional and hybrid cooperatives in the value-added agri-food industry has prompted innovation in cooperative state regulation in the USA to aid the formation and development of farm producer-owned ventures. The first innovation took place in Wyoming, which passed the Wyoming Processing Cooperative Law in 2001 to allow joint ownership by farmers and investors (Hanson 2001). ${ }^{1}$ After Wyoming, similar innovations in cooperative state law appeared in Minnesota (2003), ${ }^{2}$ Iowa (2005), ${ }^{3}$ Tennessee (2005), ${ }^{4}$ Wisconsin (2006), ${ }^{5}$ and Nebraska (2007). ${ }^{6}$ Subsequently, the Uniform Law Commission drafted the Uniform Limited Cooperative Association Act (ULCAA) in 2007 to fill a new niche in the ecosystem of cooperative modes of organization (Dean and Geu 2008). Specifically, the ULCAA facilitated the formation of the limited cooperative association (LCA), a unique hybrid structure with dual ownership by patrons and investors. Utah (2008), ${ }^{7}$ Oklahoma (2009), ${ }^{8}$ the District of Columbia (2010), ${ }^{9}$ Missouri (2011), ${ }^{10}$ Colorado (2012), ${ }^{11}$ Kentucky (2012) ${ }^{12}$ and Vermont $(2012)^{13}$ also passed versions of the ULCAA. ${ }^{14}$

However, examination of the LCA and its current standing in the agri-food industry is nonexistent. It is unknown if the innovations in cooperative state law have facilitated a viable solution to the equity constraint experienced by traditional and hybrid cooperatives. Yet improved knowledge is needed as farmer cooperatives must find equity to make necessary investments in scale and scope economies. Frequently, farmer cooperatives resort to mergers and acquisitions to grow (Merlo 2017), in part in response to various developments in its internal and external environment (Grashuis 2018). The primary purpose of the present article is therefore to examine the current standing of LCAs in the agri-food industry. The research question is as follows: Has the recent innovation in cooperative state law facilitated the formation and development of a viable ownership structure for organized farm producers? The research question is answered in part by business registration data collected in the 13 states in which LCAs or similar producer-owned business entities exist. The nature of the study is exploratory, which implies an emphasis on the formulation of general observations and hypotheses for future research in this open field.

This paper contributes to the literature by extending and expanding the ongoing discussion of the future of farmer cooperatives with an exploratory study of the LCA, a novel hybrid structure which facilitates joint ownership by farmers and investors to drive large-scale equity acquisition for business organizations with a cooperative purpose. However, according to business registration data collected from Secretaries of State, the LCA has not yet facilitated the creation of many such organizations in the agri-food industry. As will be discussed in detail in the remainder of this paper, there may exist multiple explanations. For example, there are other legal ownership structures which facilitate better opportunities to improve farmer welfare; the public may oppose the exploitation of the cooperative identity by an entity characterized in part by investor-oriented objectives; potential investors may feel reluctant to invest or retain equity in value-added ventures used by upstream stakeholders; and user-owned and user-controlled organizations may lack crucial resources and capabilities to pursue strategic advantages.

\section{The limited cooperative association}

The below description is based on the LCA as described in the ULCAA, which adopted descriptions from earlier innovations in cooperative state law in Wyoming, Minnesota, 
and Iowa (Dean and Geu 2008; Geu and Dean 2009a). Names and descriptions may vary from state to state, however. In general, the ULCAA is considered to be more flexible but also more protective of cooperative values and principles as compared to the Wyoming Processing Cooperative Law and its offshoots in Minnesota and Iowa (Dean and Geu 2008; Geu and Dean 2009a).

The key characteristic of the LCA is the possibility, but not the requirement, of investor ownership (Dean and Geu 2008). Investors may obtain ownership by purchasing common stock, preferred stock, or some other equity instrument. By comparison, patron ownership is manifested by the right and obligation to supply or deliver a given commodity such as corn or chicken. Similar to NGCs, member patrons may face substantial supply and non-redeemable equity requirements to facilitate scale economies in processing. As two distinct types of owners, member patrons and member investors receive a return on patronage and investment, respectively. However, the ULCAA contains an allocation constraint, which states member patrons must be allocated at least $50 \%$ of the profits and losses to preserve the cooperative nature of the entity. Thus, the ULCAA departs from other cooperative state law innovations in Wyoming, Minnesota, Iowa, and Tennessee, where the percentage of profits and losses allocated to member patrons may decrease to 15\%, as well as Wisconsin, which set the floor at 30\% (Geu and Dean 2009b).

In addition to member patron ownership, member patron control is also sacrificed in the LCA. Traditionally, control is held entirely by farm producers who often do not possess specific knowledge or expertise of the business environment, which is unattractive to capital investors who seek a competitive return on equity investment (Hendrikse and Veerman 2001; Dempsey et al. 2002). Therefore, investor ownership in the LCA is associated with control (Dean and Geu 2008; Geu and Dean 2009a). While the majority of the voting capacity must be held by member patrons, the voting system is flexible in practice and may follow the traditional one member, one vote approach or be informed by patronage, equity investment, or some combination thereof. In the interest of cooperative values and principles, the ULCAA mandates the election or appointment of board directors. Up to two thirds of the board directors may be outsiders, but member patrons must elect half or more of all board directors. It is possible to further enhance investor control by means of attendant loan covenants for certain decisions (Geu and Dean 2009a).

Altogether, the LCA represents a hybrid structure by combining the ownership and governance characteristics of traditional cooperatives, NGCs, and limited liability company (LLCs) (see Table 1). Geu and Dean (2009a) described the LCA as a flexible business entity characterized by strong cooperative values and principles but also departures from pure member patron ownership and control by facilitating minority investor ownership. Of course, the coexistence of two types of owners with different objectives is controversial (Kelley 2001). In general, member patrons do not seek an immediate return on equity investment but rather an outlet for farm products, even in case of ventures in the processing or manufacturing stage of the value chain (Kenkel and Park 2007; Senechal 2007; Grashuis and Cook 2018). By comparison, stereotypical member investors do emphasize a return on equity investment and should object to high farm-gate prices on principle. Member patrons and member investors thus respectively have upstream and downstream biases with limited compatibility. Similar to 
Table 1 Comparison of the ownership and governance characteristics of traditional and hybrid cooperatives

\begin{tabular}{lllll}
\hline Characteristic & $\begin{array}{l}\text { Traditional } \\
\text { cooperative }\end{array}$ & $\begin{array}{l}\text { New generation } \\
\text { cooperative }\end{array}$ & $\begin{array}{l}\text { Limited cooperative } \\
\text { association }\end{array}$ & $\begin{array}{l}\text { Limited liability } \\
\text { company }\end{array}$ \\
\hline Open membership & Yes & No & No & No \\
Farmer ownership & Yes & Yes & Yes & No \\
Farmer control & Yes & Yes & Yes & No \\
Investor ownership & No & Yes & Yes & Yes \\
Investor control & No & No & Yes & Yes \\
Share appreciability & No & Yes & Yes & Yes \\
Share transferability & No & Yes & Yes & Yes \\
Equity redeemability & Yes & No & No & No \\
Board of directors & Yes & Yes & Yes & No \\
Supply commitment & No & Yes & Yes & No \\
\hline
\end{tabular}

Sources: Brown and Merrett (2000), Chaddad and Cook (2004), Geu and Dean (2009a)

The listed characteristics are general outlines. In practice, legal structures are flexible and characteristics may be adjusted at the discretion of the board of directors or some other governance entity with authority to change the bylaws

the multi-purpose cooperative (Soboh et al. 2009), the objective function of the LCA may have too many parameters and constraints to allow a good solution for all parties. The obvious conflict in part explains why many question to what extent the LCA should be interpreted as a cooperative, both legally and operationally (Geu and Dean 2009a).

In practice, LCAs may be organized for any lawful purpose, whether or not for profit (Dean and Geu 2008; Geu and Dean 2009a). Similar to its predecessors in Wyoming and Minnesota, the earliest draft of the ULCAA targeted the formation and development of value-added ventures in the agricultural sector. In 2005, however, the Uniform Law Commission removed agriculture as the explicit beneficiary of the act by not providing a specific definition to avoid confusion and uncertainty. Instead, the ULCAA places emphasis on rural development, where rural is not synonymous with agricultural. Although the ULCAA provides many examples with farmer cooperatives as the primary subject, the LCA structure is in fact available to various collectives of producers and investors.

\section{Data}

To inform the effect of cooperative state law innovations in the agri-food industry, we collected corporation data from Secretaries of State in Wyoming, Minnesota, Iowa, Tennessee, Nebraska, Utah, Oklahoma, District of Columbia, Missouri, Kentucky, and Vermont. ${ }^{15}$ The dataset comprises an inclusive list of active and inactive business entities formed or listed under the new state statutes as processing cooperatives, LCAs, or similar organizations as of May 2017.

As illustrated in Table 2, there is great heterogeneity in the use of the new cooperative state statutes. Surprisingly, while serving as inspiration for future innovations in other states, the Wyoming Processing Cooperative Law only yielded two new business formations. A similar lack of industry interest in LCAs is observable in District of Columbia (zero), Kentucky (zero), Tennessee (two), Oklahoma (three), and Nebraska (four). By comparison, the adoption of LCAs in Missouri (65), Utah (75), and Minnesota (171) is more prolific. ${ }^{16}$ Overall, however, very few new business establishments form as 
Table 2 Nominal and relative adoption of new cooperative law statutes

\begin{tabular}{llllll}
\hline State & $\begin{array}{l}\text { Year } \\
\text { passed }\end{array}$ & Entity name & $\begin{array}{l}\text { Active (inactive) } \\
\text { LCAs }\end{array}$ & $\begin{array}{l}\text { Total new } \\
\text { businesses }\end{array}$ & $\begin{array}{l}\% \text { of Total new } \\
\text { businesses }\end{array}$ \\
\hline Wyoming & 2001 & Processing Coop. & $2(0)$ & 35,239 & $0.01 \%$ \\
Minnesota & 2003 & Coop. Association & $78(93)$ & 169,846 & $0.09 \%$ \\
lowa & 2005 & Coop. Association & $19\left(^{\mathrm{a}}\right)$ & 75,303 & $0.03 \%$ \\
Tennessee & 2005 & Processing Coop. & $0(3)$ & 143,037 & $0.00 \%$ \\
Nebraska & 2007 & Limited Coop. Association & $4(0)$ & 53,648 & $0.19 \%$ \\
Utah & 2008 & Limited Coop. Association & $28(47)$ & 78,663 & $0.08 \%$ \\
Oklahoma & 2009 & Limited Coop. Association & $3(0)$ & 63,837 & $0.00 \%$ \\
District of Columbia & 2010 & Limited Coop. Association & $0(0)$ & 20,301 & $0.00 \%$ \\
Missouri & 2011 & Coop. Association & $65\left(^{\mathrm{a}}\right)$ & 86,981 & $0.07 \%$ \\
Kentucky & 2012 & Limited Coop. Association & $0(0)$ & 39,420 & $0.00 \%$ \\
Vermont & 2012 & Mutual Benefit Enterprise & $14(3)$ & 7596 & $0.13 \%$ \\
Total & & & $213(146)$ & 773,871 & $0.05 \%$ \\
\hline No & & & & \\
\hline
\end{tabular}

${ }^{\mathrm{a}}$ No data available

LCAs. For example, almost 170,000 new businesses formed between 2003 and 2015 in Minnesota, yet only $0.09 \%$ (approximately 1 in every 1000) used the LCA structure. ${ }^{17}$ The highest percentage is observed in Vermont, where approximately 1 in every $750(0.13 \%)$ new businesses listed as mutual benefit enterprises. The LCA is therefore a novelty in the current business environment.

The data indicate at least 146 inactive LCAs. ${ }^{18}$ Unfortunately, the collected information from Secretaries of State is not rich enough to determine the exact cause of inactivity or dissolution. A comprehensive search of print media publications, including newspapers, academic publications, trade magazines, as well as online listings, also failed to provide a conclusive answer for each observation, suggesting most exited without much public interest or consequence. As such, it is unknown if LCAs experienced the same challenges as other traditional or hybrid cooperatives. For example, Grashuis and Cook (2018) listed poor management and poor market knowledge as two common reasons for the failure of many NGCs in the Upper Midwest. Also, several successful NGCs converted to other ownership structures to improve financial flexibility. Similar problems may or may not have caused failures of LCAs.

\section{Examples of LCAs}

Similarly, it is not possible to determine the former purpose or activity of each inactive entity. Therefore, Table 3 only illustrates the primary activity of active LCAs in each state. Similar to traditional cooperatives, the LCA structure is used to support diverse purposes. In many states, LCAs are most prominent in the real estate sector to facilitate joint ownership of condominiums (e.g., Whitburn Condominium Association in St. Louis, MO), other types of living communities (e.g., Madelia Mobile Village Cooperative in Madelia, MN), and homeowner associations (e.g., Heritage Cove Homeowners Association in Sandy, UT). These organizations may or may not have used outside ownership to make fixed investments in real estate. LCAs are also used by groups of employees, such as contractors (e.g., Lionsbridge Contractor Group Cooperative in Earth City, MO), gardeners (e.g., Col-yer Tree Care in Waynesville, MO), artists (e.g., Blue Mountain Artisans in 
Table 3 Primary activity of active LCAs by state

\begin{tabular}{llllllll}
\hline State & Agriculture & Housing & Recreation & Healthcare & Food retail & Other & Total \\
\hline Wyoming & 2 & 0 & 0 & 0 & 0 & 0 & 2 \\
Minnesota & 26 & 11 & 3 & 3 & 8 & 27 & 78 \\
lowa & 6 & 2 & 1 & 0 & 6 & 4 & 19 \\
Tennessee & 0 & 0 & 0 & 0 & 0 & 0 & 0 \\
Nebraska & 0 & 0 & 0 & 1 & 0 & 3 & 4 \\
Utah & 1 & 4 & 10 & 2 & 1 & 10 & 28 \\
Oklahoma & 0 & 1 & 0 & 1 & 0 & 1 & 3 \\
District of Columbia & 0 & 0 & 0 & 0 & 0 & 0 & 0 \\
Missouri & 6 & 16 & 3 & 2 & 3 & 35 & 65 \\
Kentucky & 0 & 0 & 0 & 0 & 0 & 0 & 0 \\
Vermont & 3 & 4 & 2 & 1 & 0 & 4 & 14 \\
Total & 44 & 38 & 19 & 10 & 18 & 75 & 213 \\
\hline
\end{tabular}

Blanding, UT), and stage performers (Bennington Community Theater in Bennington, VT), possibly to increase output capacity or bargaining power in input purchasing. Similarly, the LCA structure has been adopted by groups of consumers, particularly in the food retail sector (e.g., Ideal Green Market in Pequot Lakes, MN, and Wasatch Cooperative Market in Salt Lake City, UT).

\section{Examples of LCAs in the agri-food industry}

Overall, there exist 44 active LCAs owned by farm or food producers. One example is Next Big Thing, owned by 47 growers of a new apple variety invented by apple breeders at the University of Minnesota. The new variety, a cross between Honeycrisp and Zestar, is grown exclusively by member producers of the cooperative, which is thus able to control quality of its product and pursue competitive advantage by means of product differentiation. At the same time, quantity is controlled by means of the closed membership policy to ensure demand is not exceeded by supply. To gain ownership, each producer pays $\$ 10,000$ per unit of production, which is equal to 10,000 boxes. Another example is Midwest Elderberry Cooperative, formed in 2012 in response to an economic opportunity as elderberry demand increased and import supply decreased. With member producers in Minnesota, Iowa, and Wisconsin, the primary purpose of the cooperative is to facilitate scale economies by managing the regional supply of elderberries for use in wines, juices, and concentrates. Each member patron is required to purchase one share of Class A stock at $\$ 500$ in addition to an annual membership fee of $\$ 100$. Also, a $\$ 0.10$ share of Class $C$ stock grants the owner the right and the obligation to deliver one pound of elderberries to the cooperative. Associate membership, which lacks voting privileges, is available at $\$ 100$. Arguably the best example is still Mountain States Lamb Cooperative, which served as the impetus for the Wyoming Processing Cooperative Law. At its formation in 2001, the cooperative sold 324,471 Class A shares at $\$ 22$ each, with each share granting the right and obligation to deliver one market-lamb per year. The cooperative allowed investor ownership by means of Class B shares, which granted an annual return of $8 \%$ but no voting privileges or delivery obligations. Strong investor interest in the cooperative facilitated the establishment of Mountain States Rosen, a joint venture with Rosen \& Sons to integrate the full process 
from production to fabrication and distribution. ${ }^{19}$ Even so, Mountain States Lamb Cooperative is not considered a large presence in the farmer cooperative sector. ${ }^{20}$

Like the three examples in the last paragraph, most of the other LCAs in the agri-food industry also operate in niche markets, such as the non-GMO milk sector (Trace Cooperative in Minnesota), the cranberry sector (Cranberry Growers Cooperative in Wisconsin), the non-GMO corn and soybean seed sector (Genesys Grain Genetics in Iowa), or the ancient grain flour sector (Browse and Grass Growers Cooperative in Wisconsin). Relatively few LCAs exist in the commodity sector, such as Osakis Creamery Association (dairy), River Valley Cooperative (grain), and Minnesota Soybean Processors (soybean). Also, most of the LCAs in the commodity sector are older and had converted from another ownership structure. Thirteen of the 213 active LCAs (10 in Minnesota, 3 in Iowa) formed before the year 2000, which indicates not many existing business organizations choose to convert to the LCA structure. Hence, to answer the main research question of the study, the raw data indicate the innovations in cooperative state law have facilitated the formation and development of several small-scale operations in niche markets, but the LCA structure is apparently not attractive to many producers of farm commodities such as grain, milk, or sugar.

\section{The limited cooperative association in the agri-food sector}

As discussed in the foregoing section, the current adoption of the LCA structure by organized farm producers is rather underwhelming. The purpose of the present section is to raise and discuss general observations which may explain the apparent lack of industry interest in the LCA. The observations are not presented in any specific order. Also, the observations might be interpreted as null hypotheses to be tested by future empirical work. Considering the low number of observations as well as the general lack of available data on cooperatives (e.g. Grashuis and Su 2018), the case study method may present the best opportunity to test such hypotheses in a qualitative environment.

\section{Opposition to the (non)cooperative character}

The cooperative character is composed of such values and principles as democracy, equality, solidarity, independence, and cooperation (Spear 2000), which together may constitute the cooperative advantage or difference (Brown 2006). The LCA, however, is a hybrid cooperative with elements of the NGC and the LLC. Therefore, while the ULCAA ensures majority member patron ownership of the entity through the allocation constraint, Lushin (2010) argued LCAs should not be allowed to use the cooperative character if the operation is in part driven by member investors who pursue profit maximization. While acting as hybrid organizations in the marketplace, LCAs may mislead the consumer regarding its true character and thus harm actual farmer cooperatives which may use its ownership structure as its source for competitive advantage. This reasoning is why Vermont changed the entity name from LCA to mutual benefit enterprise and perhaps why other states did not adopt the UCLAA.

\section{Investor reluctance}

Partial ownership and control may not serve as sufficient incentive for outside investors to inject equity into a business owned and controlled by owners who have different 
objectives. Good governance is difficult if not impossible with member patrons who receive a return on patronage and member investors who receive a return on investment (Baarda 2006). In a similar context, Liang and Hendrikse (2013) and Deng and Hendrikse (2015) examined the tension between the upstream bias of member patrons and the downstream bias of non-member patron managers and executives. Invariably, non-member patron management is the best option if emphasis is to be placed on the downstream segment of the value chain, but control by member patrons with an upstream bias may spur inefficiencies. Also, to outside investors, the returns on business opportunities in agriculture and food and drink manufacturing are perhaps not high enough to accept the risk involved with majority member patron control.

\section{Absence of trailblazers, clusters, and donors}

In the early 1990s, the formation and success of Dakota Pasta Growers sparked a period referred to as "cooperative fever" (Harris et al. 1996; Cook and Iliopoulos 1999), which resulted in the formation of approximately 100 NGCs in the Upper Midwest. With the possible exception of Mountain States Lamb Growers, no similar trailblazer has emerged yet to demonstrate the economic viability of the LCA structure. Also, most NGCs formed in Minnesota and North Dakota, and Renville, MN, in particular became a hotbed of value-added activity (Patrie 1998; Burress et al. 2008). Although a clear cluster is absent, the fact Minnesota is also home to the most LCAs may imply its institutional environment is more conducive to collective action by individual farm producers than other states. Similarly, NGCs received financial support from various institutions, in particular the St. Paul Bank for Cooperatives and the North Dakota Agricultural Products Utilization Commission, to study the feasibility of value-added operations (Patrie 1998). Considering the possible involvement of private investors, similar support for LCAs is less likely to materialize.

\section{Potential loss of Capper-Volstead and subchapter T eligibility}

The exact federal interpretation of the cooperative state law innovations is uncertain. The Capper-Volstead Act of 1922, which facilitates limited antitrust exemption to farm producers who are organized to collectively buy or sell products, may or may not apply to business organizations whose owners are not the users (Kelley 2001). As discussed by Ferrell (2002), on numerous occasions, the federal court ruled farmer cooperatives did not qualify for Capper-Volstead protection as some member patrons did not engage in agricultural production but only processing or investing. Similar uncertainty applies to eligibility for Subchapter $\mathrm{T}$, which allows residual patron business income to be passed through by the cooperative to the member patron. Theoretically, a farmer cooperative is eligible for Subchapter $\mathrm{T}$ treatment if $50 \%$ or more of its business is conducted on behalf of member patrons who are primarily farm producers. As discussed by Geu and Dean (2009a), however, it is an open question if LCAs with member investor ownership may receive Subchapter $\mathrm{T}$ treatment as regulatory law is outside the scope and jurisdiction of the ULCAA. The potential loss of Capper-Volstead and Subchapter T eligibility is not without consequence. For example, Porter and Scully (1987) and Pasour and Rucker (2005) claimed the competitiveness of farmer cooperatives is in part driven or enhanced by preferential tax and antitrust treatment. 


\section{Relative disadvantages to other ownership structures}

The LLC has several advantages as compared to other ownership structures, including the LCA. Specifically, the LLC combines the single-tax status of partnerships and the limited liability of corporations. As compared to cooperatives, the LLC has five distinct advantages: (i) diversity of membership, (ii) greater capital exposure, (iii) greater potential to achieve threshold membership, (iv) greater community commitment, and (v) growth flexibility (Frederick 1998; Brown and Merrett 2000). In addition, non-member business income is taxable to the partners and not the business, as is the case for cooperatives.

Also, for existing cooperatives, it is not necessary to convert the ownership structure to an LCA to attract outside investment. Most large farmer cooperatives use joint ventures and subsidiaries to pursue business activities with some degree of non-member equity investment. In 2008, Eversull (2008) surveyed 208 farmer cooperatives, which together reported the use of 379 ventures for extra member and non-member business activities. The great majority of the ventures (82\%) had been formed as LLCs, with corporations, limited liability partnerships, and partnerships as other common ownership structures. Reynolds (2012) conducted a follow-up survey in 2012 and concluded the LLC remained the preferred choice of ownership structure to organize joint ventures and subsidiaries. In addition, increasingly more farmer cooperatives use a multiple stock structure with different classes of common stock and preferred stock to define and assign the rights to claim profits and control resources among members and non-members.

\section{Absence of new market failures}

Historically, the foremost reason for the formation of farmer cooperatives is some type of failure in input supply or output demand markets, in particular local and regional monopolies and monopsonies (Sexton 1990). Indeed, imperfect competition is apparent in most agri-food sectors (McCorriston 2002), although increased market concentration and vertical coordination do not necessarily indicate a market is in failure (Sexton 2013). The spot market may still allow buyers and sellers to come together at relatively low cost, in particular as new technology facilitates an improvement in price discovery and transparency (Drnevich and Croson 2013). However, while the spot market is well-developed in commodity sectors (e.g., grain, sugar), the same is not true of the specialty crop sectors in which LCAs have been observed (e.g., Next Big Thing in the apple sector; Midwest Elderberry Cooperative in the elderberry sector; Mountain States Lamb and Wool Cooperative in the lamb sector). In such sectors, the LCA structure may reduce or even minimize the cost of transacting (e.g., finding information on buyers, prices, and contracts) as compared to the spot market or the traditional cooperative.

\section{Weak market orientation}

In general, competitive advantage is often based on cost leadership or (product) differentiation. There is good reason to assume farmer cooperatives struggle with both strategies. First, farmer cooperatives have several disadvantages in terms of supply and quality control, which is why non-cooperatives are expected to be more competitive in the differentiated market (Hovelaque et al. 2009; Mérel et al. 2009). Open membership 
cooperatives face uneven supply, while closed or defined cooperatives do not always have enough producer interest. Many of the original NGCs formed during the 1990s in the Upper Midwest operated below plant capacity and failed (Grashuis and Cook 2018). Second, most farmer cooperatives have an upstream bias or user-orientation and therefore do not make large investments in branding or marketing (Hardesty 2005; Beverland 2007; Kontogeorgos 2012; Grashuis 2017). Land O'Lakes (butter), Ocean Spray (cranberries), Blue Diamond (almonds), and Organic Valley (organic milk) are some examples of the few farmer cooperatives for which differentiation is the source of competitive advantage. The general lack of differentiation by farmer cooperatives is problematic as market orientation is more likely than ownership or governance to positively impact performance (Benos et al. 2016).

\section{Conclusion}

As noted in the introduction, competition for scarce marketing opportunities is increasing (Saitone and Sexton 2017). To improve competitiveness, many cooperatives seek additional equity to make necessary net asset investments in scale and scope economies. The natural consequence is consolidation by means of mergers and acquisitions. The total number of farmer cooperatives in the USA has been declining by an annual rate of $2.58 \%$ since 2000 (see Fig. 1), and the decline is likely to continue as emphasis is placed on size and efficiency (Merlo 2017). The gradual decline may imply small traditional farmer cooperatives do not have a guaranteed future in the global marketplace. Such cooperatives may only survive in small pockets of the marketplace where original conditions for market failure still exist and low margins do not attract competitors.

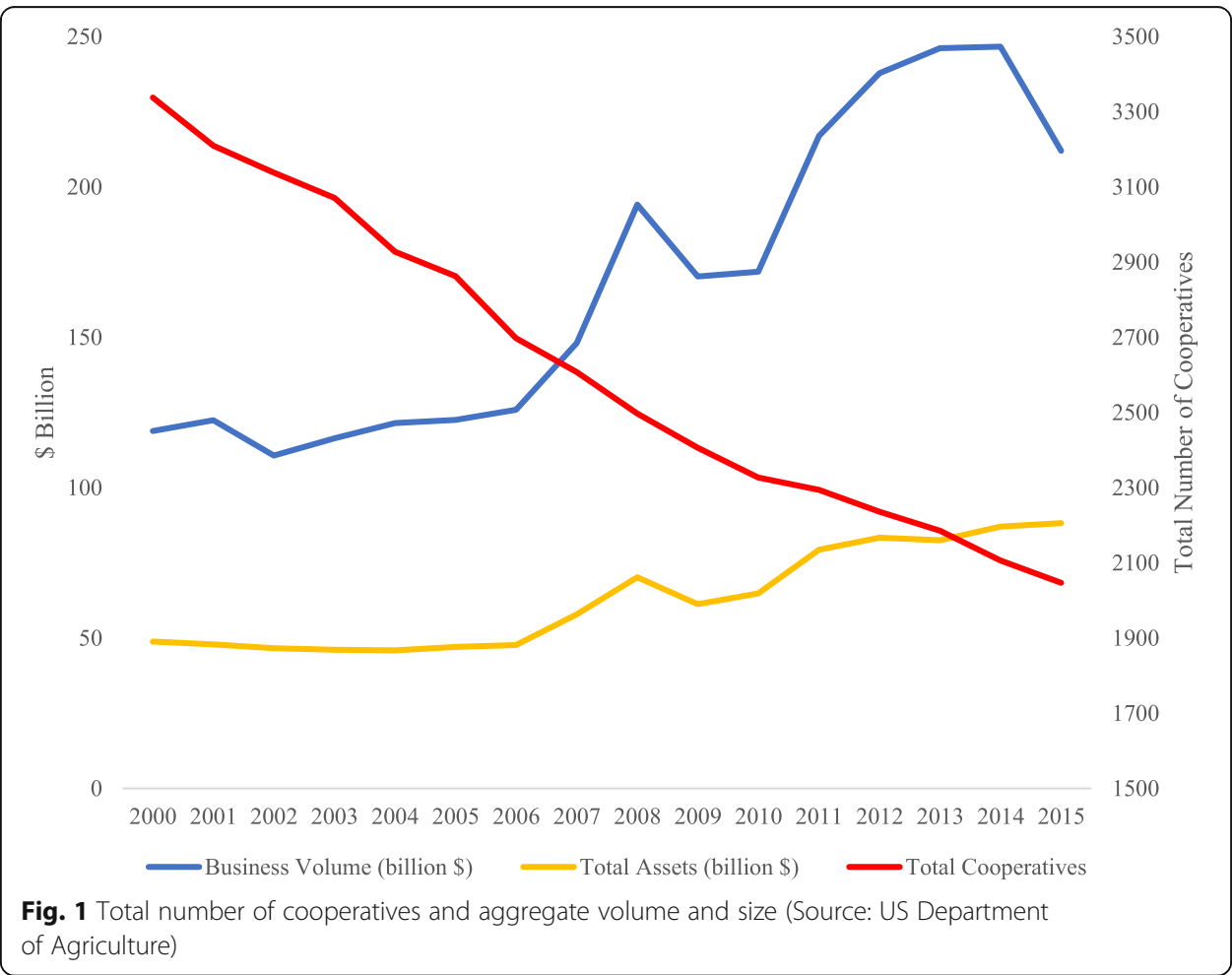


In local and regional market environments with increasingly less emphasis on pricebased competition, the current trend of fewer and larger diversified farmer cooperatives is likely to continue. However, with increased heterogeneity in member attitudes and objectives (Höhler and Kühl 2017), one can question if such organizations can remain farm producer-owned and -controlled in the long term. Many of the larger farmer cooperatives have assumed a corporate appearance. In many cases, non-member business is becoming a substantial if not overwhelming source of income for the organization. Some cooperatives have complex ownership structures with dozens of joint ventures and subsidiaries in various different industries. Are these organizations still driven by cooperative values and principles if non-member interests and objectives direct its operations? If not, will such organizations still be able to facilitate improvements in farmer welfare, more so than traditional farmer cooperatives which retain a strong member orientation with pure member patron ownership and control?

In addition to ownership structure, strategic orientation is an important factor. While the formation of traditional cooperatives has been motivated by the protection of farm asset values in market exchanges with large buyers of farm outputs and large sellers of farm inputs, Cook (1995) observed many farmer cooperatives have assumed a more offensive orientation by seeking as opposed to protecting rent. Cook (1995) further noted "the future for market-failure-correcting cooperatives that shift or restructure toward more offensive strategies and structures looks promising but challenging". Considering the limited success of NGCs and the slow adoption of the LCA structure, the transition is indeed challenging. The NGC, characterized by closed membership and substantial supply and equity commitments, generated much producer optimism in the 1990s before the conversions of several large value-added ventures in the 2000s revealed a limited ceiling. In response, innovations in cooperative state law introduced the LCA, a new legal entity to facilitate the formation and development of business organizations with joint ownership by farm producers and investors. However, business registration data collected from Secretaries of State indicate the LCA structure has not yielded many such organizations in the agri-food industry. The LCA is apparently most useful to small-scale operations in niche markets in which price discovery mechanisms and buyer-seller relationships are not as efficient as in grain, dairy, or sugar markets.

The observations inspire further discussion of the future of farmer cooperatives, including NGCs, LCAs, and other producer-owned ventures as vehicles for improving the welfare of farm producers. Traditional cooperatives, defined by pure member ownership and control, may lose competitiveness without adaptation of strategy and structure. Compromising the core cooperative values and principles, however, may invite opposition from both practitioners and policymakers, in part because the exact legal implications of combining farmer and investor ownership are not yet entirely clear. Therefore, it appears to be more practical to attract outside investment in subsidiaries of the cooperative entity to separate member patron and member investor objectives. However, the advent of large cooperatives with diversified member and non-member business activities raises the question to what extent such organizations will remain user-owned and user-controlled in the foreseeable future.

Future research and discussion may progress in several directions. For example, what is the relative use of traditional cooperatives, LCAs, LLCs, and other types of entity statutes in the agri-food industry? What do member patrons perceive as the advantages 
and disadvantages of the various ownership structures? Are there common solutions to overcome conflicts in member patron and member investor objectives? Also, what is the legal capacity for future innovations in cooperative state and federal law, such as extended eligibility for the Capper-Volstead Act, to promote farm producer ownership of value-added ventures? While the general scarcity of rich information on cooperatives is an obstacle, answers to such open questions will contribute positively to the ongoing discussion on the future role of cooperatives in the modern agri-food industry.

\section{Endnotes}

${ }^{1}$ Wyoming Processing Cooperative Law. Wyoming Statutes $\$ S$ S 17-10-201 to 17-10-253.

${ }^{2}$ Minnesota Cooperative Associations Act. Minnesota Statutes $\$ S$ 308B.001 to 308B.975.

${ }^{3}$ Iowa Cooperative Associations Act. Iowa Code $\mathbb{S S ~ 5 0 1 A . 1 0 1 ~ t o ~ 5 0 1 A . 1 2 1 6 . ~}$

${ }^{4}$ Tennessee Processing Cooperative Law. Tennessee Code $\$ S$ 43-38-101 to 43-38-1109.

${ }^{5}$ Wisconsin Cooperative Associations Act. Wisconsin Statutes $\$ \$ S ~ 193.005$ to 193.971.

${ }^{6}$ Nebraska Limited Cooperative Association Act. Nebraska Revised Statutes $\$ S$ 21-2901 to 21-29,134.

${ }^{7}$ Uniform Limited Cooperative Association Act. Utah Code $\$ S$ 16-16-101 to 16-16-120.

${ }^{8}$ Uniform Limited Cooperative Association Act. Oklahoma Statutes $\$ S \$$ 18-441-101 to 18-441-1704.

${ }^{9}$ Uniform Limited Cooperative Association Act. District of Columbia Code $\$ \$ \$$ 29-1001.01 to 29.1015.08.

${ }^{10}$ Missouri Cooperative Association Act. Missouri Revised Statutes $\$ \$ S 51.1000$ to 351.1228 .

${ }^{11}$ Colorado Uniform Limited Cooperative Association Act. Colorado Revised Statutes \$\$ 7-58-101 to 7-58-1404.

${ }^{12}$ Kentucky Uniform Limited Cooperative Association Act. Kentucky Revised Statutes S\$ 272A.1-010 to 272A.1-140.

${ }^{13}$ Mutual Benefit Enterprise Act. Vermont Statutes $11 C$ V.S.A. $\mathbb{S} 101$ to $11 \mathrm{C}$ V.S.A. $\mathbb{S}$ 1703.

${ }^{14}$ While early innovations in state law invoked the terms "processing cooperative" and "cooperative association", the paper shall henceforth only use the umbrella term "limited cooperative association" as described in the UCLAA.

${ }^{15}$ We did not collect data from Colorado because its Secretary of State categorizes LCAs as "other" entities. The same reason applies to Wisconsin, which categorizes LCAs as "miscellaneous". The Secretary of State of Wisconsin did provide a list of 21 "miscellaneous" entities which include the term "cooperative" in its name, but we cannot verify if the entities are active or inactive. Nor can we verify is there exist other LCAs which do not include the term "cooperative" in its name. Therefore, we do not further consider Colorado or Wisconsin in our analysis.

${ }^{16}$ The Secretaries of State of Iowa and Missouri did not have information on inactive entities. The two numbers therefore represent the lower limit of LCA formations. 
${ }^{17}$ Data on new business establishments is only current up to 2015. LCAs formed in 2016 and 2017 are thus not included in the percentage.

${ }^{18}$ Missouri is not included in the percentage.

${ }^{19}$ In 2008, Mountain States Lamb Cooperative bought the remaining 50\% from Rosen \& Sons to become the sole owner of the venture.

${ }^{20}$ Mountain States Lamb Cooperative is not among the top 500 largest cooperatives in terms of total sales.

\section{Abbreviations}

LCA: Limited cooperative association; LLC: Limited liability company; NGC: New generation cooperative; ULCAA: Uniform Limited Cooperative Association Act

\section{Acknowledgements}

Not applicable.

Funding

Not applicable.

\section{Availability of data and materials}

Not applicable.

\section{Authors' contributions}

The author read and approved the final manuscript.

\section{Competing interests}

The author declares that he/she has no competing interests.

\section{Publisher's Note}

Springer Nature remains neutral with regard to jurisdictional claims in published maps and institutional affiliations.

\section{Received: 24 November 2017 Accepted: 22 November 2018}

Published online: 12 December 2018

\section{References}

Baarda J (2006) Current issues in cooperative finance and governance. In: Cooperative programs, rural development. U.S. Department of Agriculture, Washington, D.C.

Benos T, Kalogeras N, Verhees FJ, Sergaki P, Pennings JM (2016) Cooperatives' organizational restructuring, strategic attributes, and performance: the case of agribusiness cooperatives in Greece. Agribusiness 32(1):127-150

Beverland M (2007) Can cooperatives brand? Exploring the interplay between cooperative structure and sustained brand marketing success. Food Policy 32(4):480-495

Brown L (2006) Innovations in co-operative marketing and communications. Centre for the Study of Co-operatives, University of Saskatchewan, Saskatoon

Brown RB, Merrett CD (2000) The limited liability company versus the new generation cooperative: alternative business forms for rural economic development. In: ) (ed) Illinois Institute for Rural Affairs, Rural Research Report 11. Illinois Institute for Rural Affairs, Macomb

Burress MJ, Cook ML, Klein PG (2008) The clustering of organizational innovation: developing governance models for vertical integration. Int Food Agribusiness Manage Rev 11(4):49-75

Chaddad FR, Cook ML (2004) Understanding New Cooperative Models: An Ownership-Control Rights Typology. Rev Agric Econ 26(3):348-360

Cook ML (1995) The future of US agricultural cooperatives: a neo-institutional approach. Am J Agric Econ 77(5):1153-1159

Cook ML, lliopoulos C (1999) Beginning to inform the theory of the cooperative firm: emergence of the new generation cooperative. Finn J Bus Econ 4(99):525-535

Dean JB, Geu TE (2008) The uniform limited cooperative association act: an introduction. Drake J Agric Law 13:63-113

Dempsey JJ, Kumar AA, Loyd B, Merkel LS (2002) A value culture for agriculture: to become high-performing businesses, agricultural co-ops must move away from their traditional role as service providers. McKinsey Q(Summer):64-76. https:// go.galegroup.com/ps/i.do?p=AONE\&sw=w\&u=googlescholar\&v=2.1\&it=r\&id=GALE\%7CA90192563\&sid=classroom Widget\&asid $=00032 \mathrm{fdb}$

Deng W, Hendrikse GW (2015) Managerial vision bias and cooperative governance. Eur Rev Agric Econ 42(5):797-828

Drnevich PL, Croson DC (2013) Information technology and business-level strategy: toward an integrated theoretical perspective. MIS Q 37(2):483-509

Eversull E (2008) Co-ops ring up additional \$14 billion in sales via other ownership structures. Rural Coop 75(6):18-19 Ferrell SL (2002) New generation cooperatives and the capper-Volstead act: playing a new game by the old rules. Okla City UL Rev 27:737-771

Frederick DA (1998) The impact of LLCs on cooperatives: bane, boon, or non-event? J Coop 13:44-52

Geu TE, Dean JB (2009a) The new uniform limited cooperative association act: a capital idea for principled self-help value added firms, community-based economic development, and low-profit joint ventures. Real Property Trust Estate Law J 44(1):55-205 
Geu TE, Dean JB (2009b) The uniform limited cooperative act: comparative leverage points and principles. Coop Account 62(1):3-12

Grashuis J (2017) Branding by farmer cooperatives: an empirical study of trademark ownership. J Coop Organ Manag 5(2):57-64 Grashuis J (2018) An exploratory study of cooperative survival: strategic adaptation to external developments. Sustainability 10(3):652

Grashuis J, Cook M (2018) An examination of new generation cooperatives in the upper midwest: successes, failures, and limitations. Ann Public Coop Econ 89(4):623-644

Grashuis J, Su Y (2018) A review of the empirical literature on farmer cooperatives: performance, ownership and governance, finance, and member attitude. Ann Public Coop Econ. https://doi.org/10.1111/apce.12205

Hanson M (2001) A new cooperative structure for the 21st century: the Wyoming processing cooperative law. Coop Account Fall 2001:3-9

Hardesty SD (2005) Cooperatives as marketers of branded products. J Food Distrib Res 36(1):237-242

Harris A, Stefanson B, Fulton M (1996) New generation cooperatives and cooperative theory. J Coop 11(6):15-28

Hendrikse GW, Veerman CP (2001) Marketing co-operatives: an incomplete contracting perspective. J Agric Econ 52(1):53-64

Höhler J, Kühl R (2017) Dimensions of member heterogeneity in cooperatives and their impact on organization - a literature review. In: Annals of public and cooperative economics. https://doi.org/10.1111/apce.12177

Hovelaque V, Duvaleix-Tréguer S, Cordier J (2009) Effects of constrained supply and price contracts on agricultural cooperatives. Eur J Oper Res 199(3):769-780

Kelley CR (2001) New generation farmer cooperatives: the problem of the just investing farmer. NDL Rev 77:185-246

Kenkel P, Park J (2007) Business models and producer-owned ventures: choices, challenges, and changes. J Agric Appl Econ 39(2):381-387

Kontogeorgos A (2012) Brands, quality badges and agricultural cooperatives: how can they co-exist? TQM J 24(1):72-82

Liang Q, Hendrikse GW (2013) Cooperative CEO identity and efficient governance: member or outside CEO? Agribusiness 29(1):23-38

Lushin L (2010) A Trojan horse in our midst: ten faults of the limited cooperative association act. Coop Grocer 151:28-29

McCorriston S (2002) Why should imperfect competition matter to agricultural economists? Eur Rev Agric Econ 29(3):349-371

Mérel PR, Saitone TL, Sexton RJ (2009) Cooperatives and quality-differentiated markets: strengths, weaknesses, and modeling approaches. J Rural Coop 37(2):201-224

Merlo C (2017) Crossing the merger finish line. In: Rural Cooperatives, September/October 2017. U.S. Department of Agriculture, Washington, D.C.

Pasour EC, Rucker RR (2005) Plowshares and pork barrels: the political economy of agriculture. The Independent Institute, Oakland

Patrie W (1998) Creating co-op fever: a rural developer's guide to forming cooperatives. In: Rural Business-Cooperative Service, Service report 54. U.S. Department of Agriculture, Washington, D.C.

Porter PK, Scully GW (1987) Economic efficiency in cooperatives. J Law Econ 30(2):489-512

Reynolds B (2012) Joint ventures and subsidiaries of agricultural cooperatives. In: Rural Business and Cooperative Programs, research report 226. U.S. Department of Agriculture, Washington, D.C

Saitone TL, Sexton RJ (2017) Concentration and consolidation in the U.S. food supply chain: the latest evidence and implications for consumers, farmers, and policymakers. Econ Rev 102:25-59 Federal Reserve Bank of Kansas City

Senechal D (2007) Value-added business success factors-the role of investor attitudes and expectations. Ag Decision Maker 2007:5-6

Sexton RJ (1990) Imperfect competition in agricultural markets and the role of cooperatives: a spatial analysis. Am J Agric Econ 72(3):709-720

Sexton RJ (2013) Market power, misconceptions, and modern agricultural markets. Am J Agric Econ 95(2):209-219

Soboh RAME, Lansink AO, Giesen G, van Dijk G (2009) Performance Measurement of the Agricultural Marketing Cooperatives:

The Gap between Theory and Practice. Rev Agric Econ 31(3):446-469

Spear R (2000) The co-operative advantage. Ann Public Coop Econ 71(4):507-523

\section{Submit your manuscript to a SpringerOpen ${ }^{\circ}$ journal and benefit from:}

- Convenient online submission

- Rigorous peer review

- Open access: articles freely available online

- High visibility within the field

- Retaining the copyright to your article

Submit your next manuscript at $\boldsymbol{\nabla}$ springeropen.com 